(1) Norræna ráô̌herranefndin

Ársskýrsla

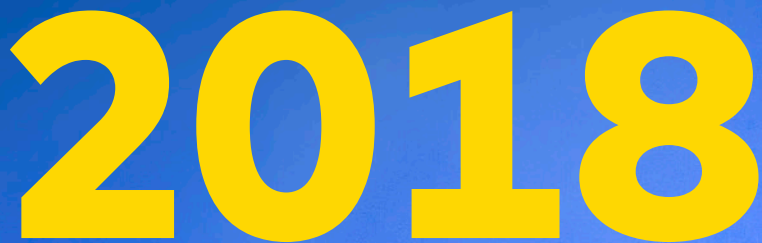

Ár norræns notagildis
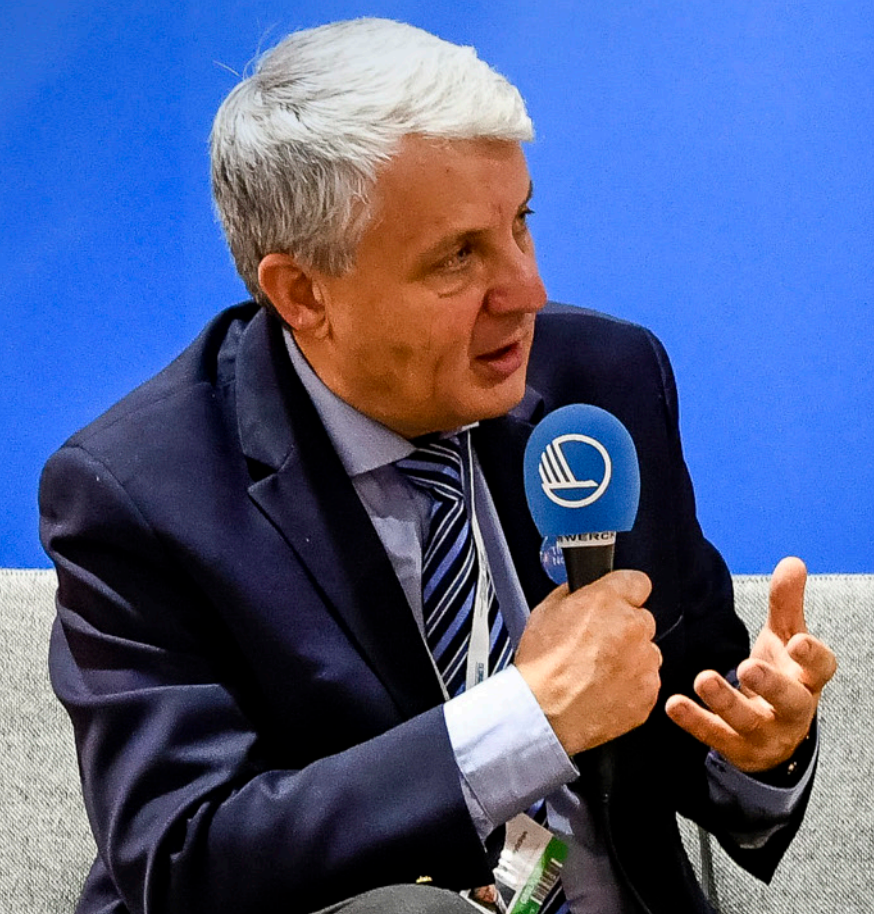

(1) DEBEITWORKAND

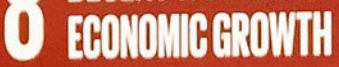

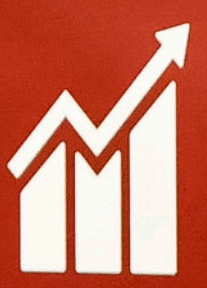

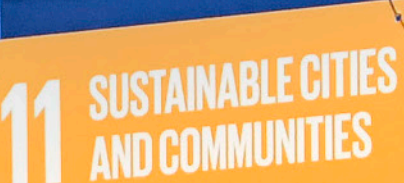

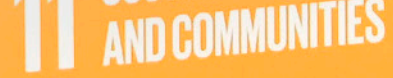
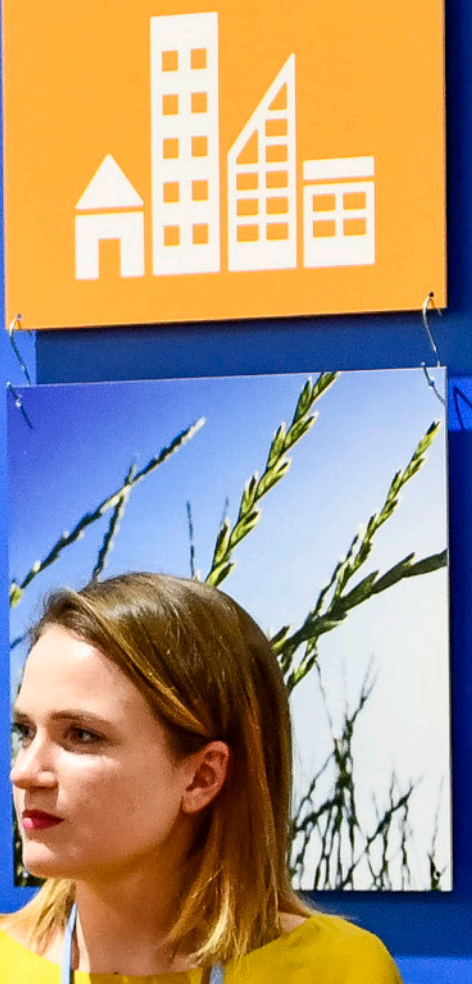


\section{Ársskýrsla 2018 - Ár norræns notagildis}

PolitikNord 2019:724

ISBN 978-92-893-6130-9 (PRINT)

ISBN 978-92-893-6131-6 (PDF)

ISBN 978-92-893-6132-3 (EPUB)

http://dx.doi.org/10.6027/PN2019-724

(c) Norræna ráðherranefndin 2019

Umbrot: Louise Jeppesen

Kápumynd: Robert Bednarczyk - norden.org. Ljósmynd tekin á COP24.

\section{Norrænt samstarf}

Norræna samstarfið er eitt umfangsmesta svæðissamstarf í heimi. Að samstarfinu koma Danmörk, Finnland, Ísland, Noregur og Svípjóð auk Álandseyja, Færeyja og Grænlands.

Norræna samstarfið er pólitískt, efnahagslegt og menningarlegt og lætur muna um sig í evrópsku og alpjóðlegu samstarfi. Löndin stuðla sameiginlega að öflugum Norðurlöndum í öflugri Evrópu.

Með norrænu samstarfi er hagsmuna svæðisins gætt og norræn gildi efld í hnattrænu samhengi. Sameiginleg gildi landanna styrkja stöðu Norðurlanda og skipa peim meðal peirra svæða í heiminum par sem nýsköpun og samkeppnishæfni er mest.

\section{Norræna ráôherranefndin}

Nordens Hus

Ved Stranden 18

DK-1061 Kaupmannahöfn

www.norden.org

Hlaða niður og panta norræn rit: www.norden.org/nordpub 


\section{Efnisyfirlit}

$\begin{array}{lr}\text { Formáli } & 5\end{array}$

$\begin{array}{ll}\text { Átak í bágu aukins hreyfanleika } & 7\end{array}$

Áfram áhersla á að̋lögun $\quad 8$

$\begin{array}{ll}\text { Nordplus fagnar afmæli } & 8\end{array}$

$\begin{array}{ll}\text { Aukið samstarf um 5G og gervigreind } & 9\end{array}$

$\begin{array}{ll}\text { Norðurlönd og umheimurinn } & 10\end{array}$

Skýrslur vöktu eftirtekt á albjóðavettvangi 12

$\begin{array}{ll}\text { Forsætisráðherraverkefnið á fullri ferð } & 13\end{array}$

$\begin{array}{ll}\text { Skilvirkara samstarf vegna umbóta } & 14\end{array}$ 


\section{Formáli}

Árið 2018 var afar mikið um að vera hjá Norrænu rádherranefndinni og kom greinilega í ljós á árinu að norrænt samstarf skilar raunverulegum árangri á mörgum sviðum.

Meðal annars skilaði okkur verulega áfram við að gera að veruleika sameiginlega framtíðarsýn Norðurlanda og Eystrasaltsríkjanna um að svæðið taki alpjóðlega forystu í próun á 5G-tækni og stafvæðingu. Er einkar ánægjulegt að sjá hve vel vinnan fór af stað við að láta rafræn auðkenni landanna gilda pvert á norræn og baltnesk landamæri. Petta er verkefni sem getur orðið jafnmikilvægt fyrir ferðafrelsið og vegabréfasambandið var á sínum tíma og bví verður mikil áhersla lögð á pað.

Einnig var ánægjulegt að Stjórnsýsluhindranaráðið, sem greiðir götu hreyfanleika á Norðurlöndum, afkastaði meiru en nokkru sinni fyrr. Aldrei hafa fleiri stjórnsýsluhindranamál verið afgreidd á einu ári eins og eftir að ráðið fékk aukið umboð árið 2018.

Við getum einnig verið ánægð með árangurinn af alpjóðastarfinu á árinu. Við próuðum áfram vel heppnað verkefni um norræn nýsköpunarhús víða um heim og opnuðum tvö ný, Nordic Innovation House í Hong Kong og einnig í Singapúr. Pannig bjuggum við til vettvang fyrir norræn fyrirtæki sem vilja sækja inn á Asíumarkaðinn. Við opnuðum einnig fyrir auknu samstarfi við Kína, meðal annars um sjálfbærar borgir.

Enn fremur vorum við með samnorrænan vettvang á loftslagsráðstefnunni COP24 í Katowice, par sem okkur gafst tækifæri til að kynna gestum hvaðanæva að lausnir okkar í loftslagsmálum í anda forsætisrádherraverkefnisins Norrænar lausnir á hnattrænum viðfangsefnum.
Fór heldur ekki framhjá okkur að norrænar skýrslur greiningardeildarinnar okkar vöktu mikla athygli hjá albjóðlegum fjölmiðlum.

Á árinu 2018 var staðfest að pær umbætur sem við höfum ráðist í á undanförnum árum til að auka skilvirkni í norrænu samstarfi hafa heppnast vel. Mér er pað mikið gleðiefni að matið á Nytt Norden sem gert var árið 2018 sýnir reglulega góðan árangur. Samstarfið er orðið skilvirkara og nýtist betur löndunum sem að pví standa og íbúum peirra. Pað sýnir að við erum á réttri leið. Jafnframt hefur pað orðið til pess að löndin gera auknar kröfur og bera meiri væntingar til samstarfsins. Við hjá ráðherranefndinni skorumst ekki undan slíkri áskorun.

I pessari samantekt má lesa nokkuð um ávinninginn árið 2018. Petta er alls ekki tæmandi upptalning. Norrænt samstarf er yfirgripsmikið og fjölmargir koma að pví svo að ógerlegt er að nefna allt. Hér beinum við kastljósinu að nokkru af pví sem vegur pyngst.

Ég get með ánægju sagt að við höfum náð mörgum mikilvægum áföngum sem sömuleiðis boðar gott fyrir samstarfið i framtíðinni.

\section{Dagfinn Høybråten,}

framkvæmdastjóri

Norrænu ráðherranefndinni 

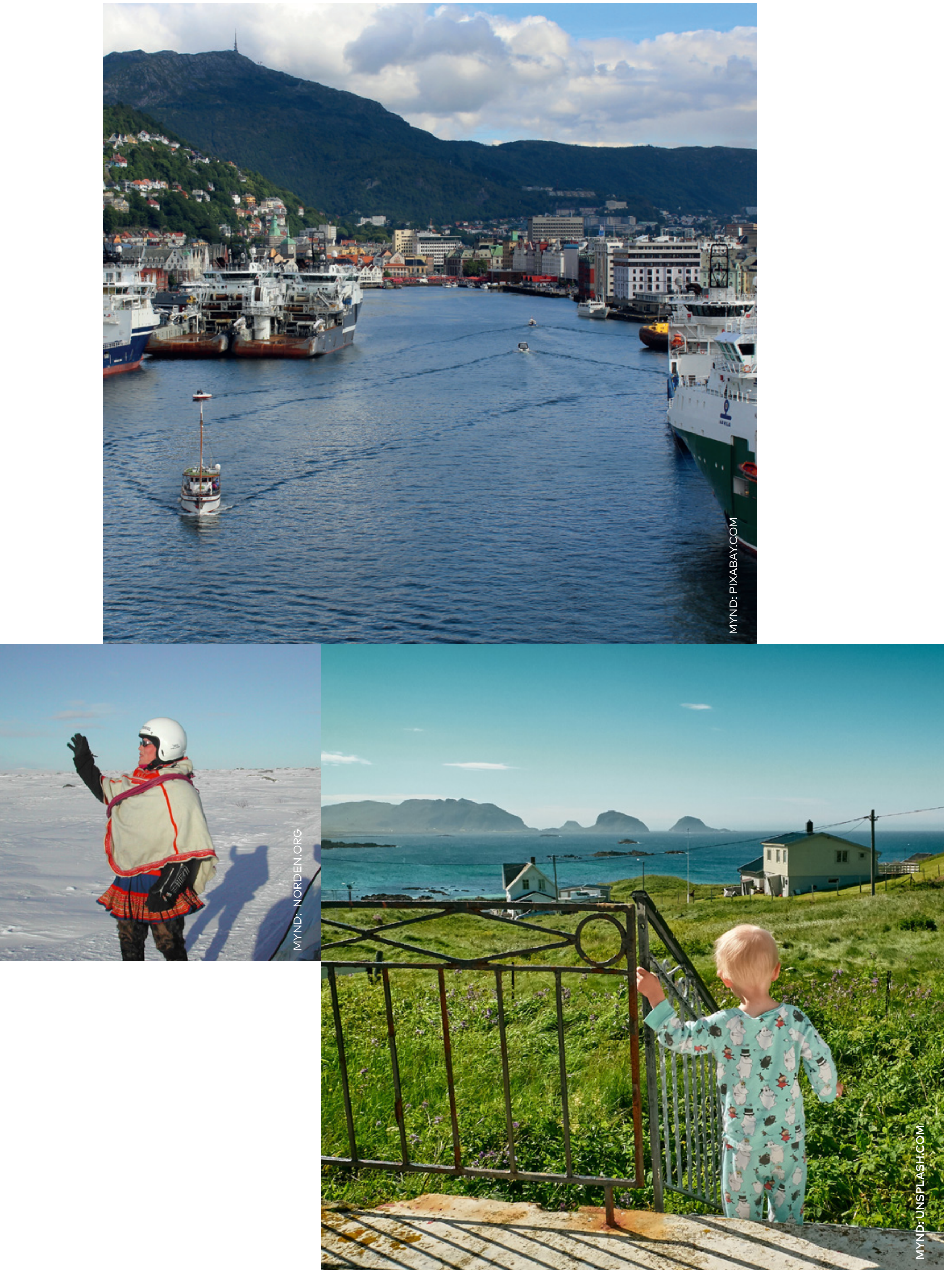


\section{Átak í págu aukins hreyfanleika}

Norrænu samstarfsráðherrarnir ákváðu að rýmka verksvið Stjórnsýsluhindranaráðsins fyrir árið 2018. Ráðið fékk par með aukið svigrúm til að vinna náið með ráðherrum og samstarfsnetum og pað hefur skilað árangri. Árið 2018 tókst Stjórnsýsluhindranaráðinu að afgreiða fjórtán hindranir fyrir frjálsa för á Norðurlöndum sem er met; prettán hindrunum var rutt úr vegi og ein afskrifuð pví að úr henni varð ekki bætt. Með lagabreytingum í Svípjóð var meðal annars leyst úr premur veigamiklum hindrunum er vörðuðu atvinnuleysistryggingar peirra sem sækja vinnu yfir landamæri, ráðstöfun sem tók til um 35 púsund farandstarfsmanna.

Verkefni Stjórnsýsluhindranaráðsins felst í pví að fá ríkisstjórnir landanna til að afnema hindranir sem torvelda frjálsa för og verða til pegar yfirvöld túlka reglur með mismunandi hætti eða löggjöf landanna stangast á.

\section{$\rightarrow$ SJÁ NÁNAR SKÝRSLU STJÓRNSÝSLUHINDRANARÁĐSINS}

Aukinn hreyfanleiki er með mikilvægustu verkefnum Norrænu ráðherranefndarinnar og liður í peirri viðleitni var útgáfa skýrslu um frjálsa för í júní 2018. Í skýrslunni Norðurlönd - ný tækifæri er bent á ýmsa málaflokka sem Norðurlönd geta unnið betur að saman til að greiða fyrir hreyfanleika milli landa fyrir fólk og fyrirtæki.

\section{$\rightarrow$ SJÁ NÁNAR SKÝRSLUNA NORĐURLÖND - NÝ TAEKIFAERI}

Í skýrslunni, sem Ingvard Havnen, fyrrverandi sendiherra Noregs í Danmörku, tók saman, eru sextán tillögur að auknum hreyfanleika á Norðurlöndum. Einna ríkust áhersla er lögð á tillögu um að Norðurlandabúar geti notað rafræn auðkenni sín hvar sem er á Norðurlöndum í síðasta lagi árið 2020. Petta verkefni er talið marka jafnmerkileg tímamót og vegabréfasambandið á sínum tíma. Tillagan nýtur forgangs hjá Norrænu ráðherranefndinni sem heldur áfram að vinna að framgangi hennar árið 2019. Samstarfið um rafræn auðkenni tekur einnig til Eystrasaltsríkjanna.

Á árinu var einnig tekið til við að semja framkvæmdaáætlun um aukinn hreyfanleika, meðal annars á grundvelli skýrslunnar eftir Ingvard Havnen.

Árið 2018 var svokallaður Arjeplogsamningur undirritaður eftir viðræður í átta ár. Samið var um endurskoðaða gerð Arjeplogsamningsins í peim tilgangi meðal annars að laga hann að tilskipuninni um viðurkenningu starfsréttinda.

Samkvæmt samningnum öðlast ákveðnir hópar starfsmanna á heilbrigðissviði, sem hafa viðurkennd starfsréttindi í einu norrænu landi, rétt til að fá starfsréttindi sín viðurkennd á sömu forsendum í samræmi við tilskipunina í öðrum norrænum löndum auk Grænlands og Færeyja. Auk pess greiðir samningurinn fyrir upplýsingagjöf milli landanna um eftirlit með ákveðnum hópum heilbrigðisstarfsmanna í pví skyni að auka öryggi sjúklinga. Arjeplogsamningurinn var fyrst gerður árið 1993.

Samningurinn um aðgang námsmanna að æðri menntun á Norðurlöndum var enn fremur undirritaður árið 2018. Um er að ræða endurskoðun á eldra samkomulagi par sem aðilar skuldbundu sig til að heimila námsmönnum annars norræns lands aðgang að æðri menntun í sínu landi með sömu skilyrðum og umsækjendur í eigin landi. Samkomulagið er upprunalega frá árinu 1996 og hefur verið endurskoðað nokkrum sinnum. 


\section{Áfram áhersla á aðlögun}

Árangurinn af fyrstu norrænu samstarfsáætluninni á sviði aðlögunar 2016-2018 hefur verið góður. Í framhaldi af henni sambykktu samstarfsráðherrarnir í október nýja samstarfsáætlun á sviði aðlögunar fyrir tímabilið 2019-2021. Stefnan er að auka skilvirkni í miðlun pekkingar og reynslu á sviði aðlögunar á Norðurlöndum og einnig að styrkja innviði pess samstarfs sem byggt var upp í fyrri samstarfsáætlun.

Samkvæmt rannsókn ráðgjafafyrirtækisins Rambøll finnst stjórnvöldum á Norðurlöndum fyrri samstarfsáætlun hafa verið bæði gagnleg og mikilvæg. Upplýsingar sem hafa orðið aðgengilegar gegnum samstarfsnet, útgefin rit og vinnustofur undir merkjum samstarfsáætlunarinnar hafa auðveldað aðlögunarstarfið.

Fyrirbyggjandi starf gegn öfgastefnum er liður í nýju samstarfsáætluninni. Áætlunin nær sem fyrr til allra málaflokka.

\section{$\rightarrow$ SJÁ NÁNAR UM AĐLÖGUN}

\section{Nordplus fagnar afmæli}

Árið 2018 markaði 30 ára afmæli Nordplus á sviði norræns samstarfs og 10 ára afmæli samstarfs milli Norðurlanda og Eystrasaltsríkjanna. Afmælinu var fagnað á pingi Norðurlandaráðs í Ósló í október.

Nordplus er meðal pess í norrænu samstarfi sem mesta hrifningu hefur vakið en pað er umfangsmesta menntaáætlun ráoherranefndarinnar fyrir símenntun. Ráðherranefndin úthlutar Nordplus um pað bil 80 milljónum danskra króna á ári til verkefna á sviði menntunar og tungumála fyrir alla aldurshópa frá peim langyngstu til peirra langelstu.

Meira en 7000 námsmenn og rúmlega 1600 kennarar frá Norðurlöndum og Eystrasaltsríkjunum taka árlega pátt í Nordplus sem með beinum hætti stuðlar að hærra menntunarstigi á Norðurlöndum og í Eystrasaltsríkjunum. Einnig styrkist norræn sjálfsvitund og tungumálaskilningur par sem námsmenn og kennarar fá tækifæri til að dvelja í öðru norrænu eða baltnesku landi.

\section{$\rightarrow$ SJÁ NÁNAR UM NORDPLUS}

Prjátíu ára afmæli Nordplus var haldið í tengslum við ping Norðurlandaráðs í Ósló.

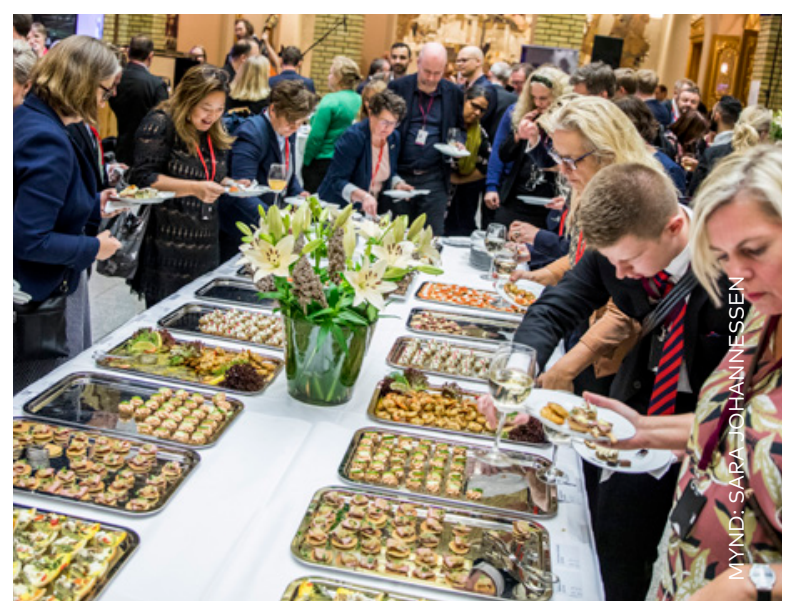




\section{Aukið samstarf um 5G og gervigreind}

Samstarfi Norðurlanda og öflugu samstarfi peirra við Eystrasaltsríkin um 5G-netið og gervigreind var haldið áfram árið 2018.

\begin{abstract}
Á Norðurlandaráðspinginu í Ósló í október var kynnt framkvæmdaáætlun um uppbyggingu 5G-nets á Norðurlöndum og í Eystrasaltslöndunum. Löndin ætla sér að byggja upp $5 G$ á svæðinu í nánu samstarfi og að styðja próun og notkun nýrrar tækni sem byggist á 5G.
\end{abstract}

Framkvæmdaáætlunin er liður í stefnu forsætisráðherra Norðurlanda um að Norðurlönd verði fremst í heimi á sviði 5G. Norrænu-baltnesku áætluninni er ætlað að tryggja að tíðnisvið í löndunum verði samræmd og pau búin undir að verða tilraunasvæði fyrir $5 G$-tæknina óháð landamærum. Petta felur í sér að Norðurlönd og Eystrasaltsríkin verða að vera betur undirbúin og geta til dæmis opnað fyrir umferð sjálfakandi vöruflutningabifreiða milli landanna eins og væru pau eitt sampætt svæði pann dag sem slíkt verður að veruleika.

Enn fremur hafa Norðurlönd og Eystrasaltsríkin komið sér saman um að efla samstarf sitt um próun og samfélagslega notkun gervigreindar.
Með nánara samstarfi um stafræna hæfni og greiðari aðgang að opinberum talnagögnum geta norrænu og baltnesku löndin hagnýtt sér stafrænt forskot og tekið forystu í próun og notkun snjallra stafrænna lausna.

Gervigreind ryður braut nýjum stafrænum lausnum sem eru til pess fallnar að leysa áskoranir samfélagsins í framtíðinni og koma til dæmis að miklu gagni á sviði heilbrigðis- og samgöngumála. Meðal annars er um að ræða lausnir er varða fyrirbyggjandi heilbrigðispjónustu, greiningar, meðhöndlun og endurhæfingu. Á samgöngusviðinu getur til að mynda góð miðlun talnagagna leitt til snjallari, skilvirkari og sampættari lausna fyrir bá sem nýta sér almenningssamgöngur. Sömuleiðis má nefna tilraunir til að bæta umferðarmynstur og reynslu ökumanna af umferðinni eins og framast er kostur en í pví sambandi er unnt að byggja á slíkum staðtölum til að finna út hvaða leið frá einum stað til annars er best og sparar mest eldsneyti.

Löndin vænta mikillar hagkvæmni af gervigreind. Með norræna-baltneska átakinu er lögð áhersla á að próa og hvetja til notkunar á gervigreind svo að hún komi íbúunum að sem bestum notum.

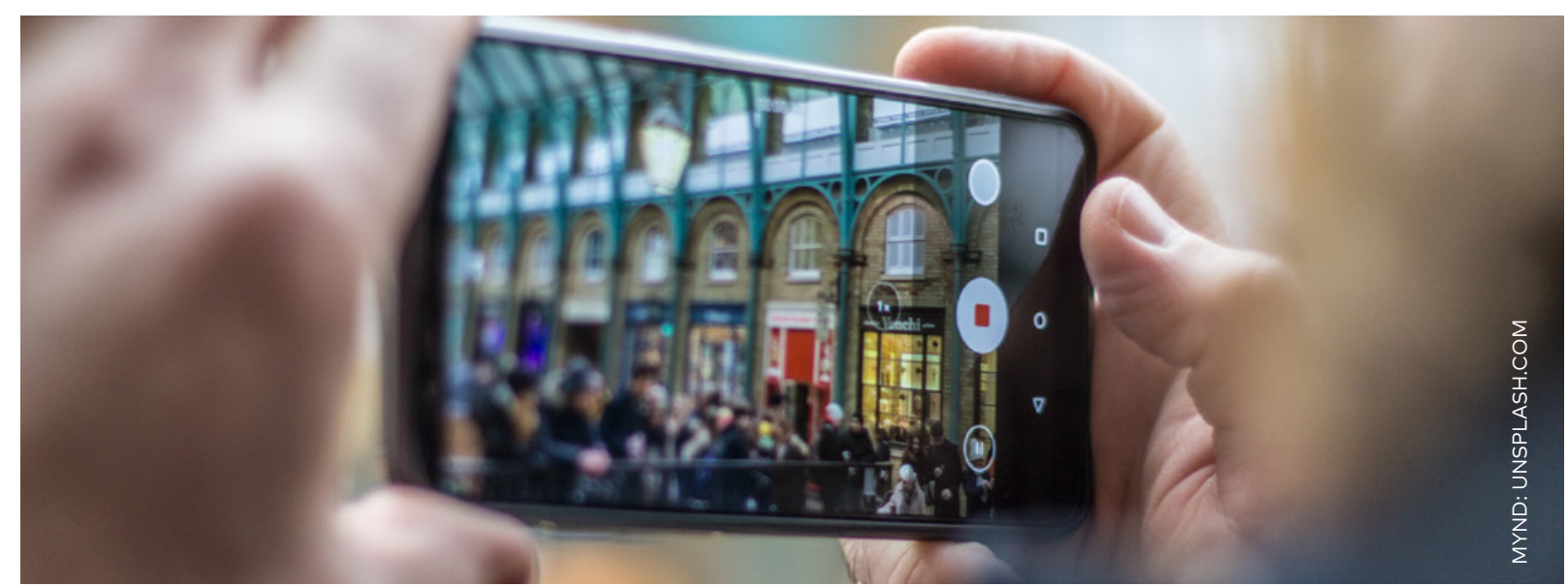




\section{Norðurlönd og umheimurinn}

Norræna ráðherranefndin lét áfram til sín taka á alpjóðavettvangi árið 2018. Til dæmis voru opnuð nýsköpunarhúsin Nordic Innovation House í Singapúr og í Hong Kong.

Tilgangur nýsköpunarhúsanna er að styðja við bakið á norrænum frumkvöðlum og fyrirtækjum sem hafa mikla alpjóðlega vaxtarmöguleika á svæðum sem pau starfa á. Norðurlönd njóta mikillar virðingar á heimsvísu og norræn fyrirtæki geta nýtt sér pað með aðstoð nýsköpunarhúsanna. Norðurlönd sem heild vekja einnig meiri áhuga alpjóðlegra fjárfesta og eru sameinuð líklegri til að laða til sín fjármagn en löndin hvert fyrir sig. Auk pess geta löndin skipt kostnaði á milli sín með pví að vinna saman.

Nýsköpunarhúsin tvö í Asíu grundvallast á sömu velheppnuðu hugmynd og byggt er á í Silicon Valley og New York par sem nýsköpunarhús hafa verið starfrækt um skeið. Verkefnið Nordic Innovation House er samstarf Nordic Innovation, stofnunar sem heyrir undir Norrænu ráðherranefndina, og útflutnings- og fyrirtækjasamtaka nokkurra norrænna landa.

\section{$\rightarrow$ SJÁ NÁNAR UM NORDIC INNOVATION}

Árið 2018 voru opnuð tvö nýsköpunarhús, Nordic Innovation House í Singapúr og í Hong Kong.

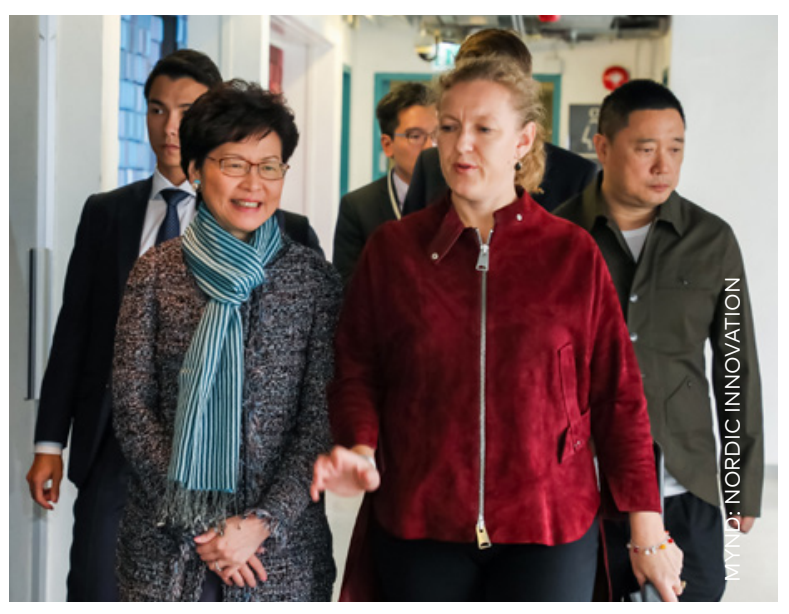

Pátttakan í loftslagsráðstefnunni COP24 í pólsku borginni Katowice var umfangsmikið alpjóðlegt verkefni á vegum ráðherranefndarinnar árið 2018. Svo sem áður lagði ráðherranefndin til norrænan sýningarskála undir sömu almennu yfirskrift og forsætisráðherraverkefnið Norrænar lausnir á hnattrænum viðfangsefnum.

Á ellefu dögum í desember stóð ráðherranefndin ásamt ýmsum samstarfsaðilum fyrir 65 viðburðum í skálanum og með mismunandi pema hvern dag. Sjálfbærni, jafnrétti og sjónarhorn ungmenna, pað er að segja málaflokkar sem hafa gengið eins og rauður práður gegnum öll fagsvið ráðherranefndarinnar og pvert á alla starfsemi, voru einnig mjög áberandi í starfseminni á COP24. Alla dagana var vakin athygli á sjónarhorni ungmenna sem létu að sér kveða í flestum dagskráratriðum. Sjónarhorns ungmenna gætti einkanlega á opnunardaginn sem kallaður var Youth Day. Pann dag voru allir viðburðir um ungt fólk og sjálfbæra próun.

Alls tóku 2300 manns pátt í viðburðum Norrænu ráðherranefndarinnar í sýningarskálanum og 12.500 horfðu á beint streymi frá Morning talk og Afternoon brief á netinu. Samkvæmt könnun sem var gerð eftir að COP24 lauk voru bæði gestir og skipuleggjendur ánægðir með norræna skálann. Hvorki meira né minna en 95 prósent sögðust ánægð eða mjög ánægð. Mikill meirihluti var jafnframt peirrar skoðunar að viðburðirnir væru góðir og ættu erindi í samtímanum.

Árið 2018 einbeitti ráðherranefndin sér einnig að samstarfinu í austri. Meðal annars var lokið sjö ára styrkjaáætlun um samstarf ráðherranefndarinnar og ESB um styrkveitingar til ungra námsmanna frá Hvíta-Rússlandi fyrir öllum útgjöldum vegna háskólanáms í aðildarríkjum ESB/EES.

\section{$\rightarrow$ SJÁ NÁNAR UM COP24}


Skrifstofa Norrænu ráðherranefndarinnar í Danmörku, skrifstofa ráðherranefndarinnar í Litáen og sendinefnd ESB í Hvíta-Rússlandi hafa unnið náið saman að framkvæmd áætlunarinnar. Markmiðið var að veita næstu kynslóð háskólamanna í Hvíta-Rússlandi stuðning og stuðla að próun lýðræðis og borgaralegs samfélags. Áætlunin á pátt í að 300 hvítrússneskir námsmenn luku háskólaprófi á árunum 2011-2018.

Norræna ráðherranefndin ákvað jafnframt á árinu 2018 að halda áfram að styrkja fjölmiðla minnihlutahópa í Eistlandi, Lettlandi og Litáen. Styrkurinn er ætlaður óháðri vandaðri fjölmiðlun á rússnesku og er framhald á fyrri styrkjaáætlun sem heppnaðist vel. Hugmyndin er að rússneskumælandi íbúar í Eystrasaltsríkjunum hafi aðgang að óháðum fréttaflutningi um málefni sem pá varða á peirra eigin tungumáli og hafi val um aðra fjölmiðla en pá rússnesku sem nú eru langalgengastir hjá rússneskumælandi pjóðarbrotum baltnesku landanna. Tilgangurinn er að veita rússneskumælandi minnihluta kost á frekari aðlögun og áhrifum og par með efla lýðræðið.

Nánara samstarf við Kína var enn fremur á dagskrá í alpjóðastarfinu. Árið 2017 urðu ráðherranefndin og Kína sammála um að hefja samstarf sem hrundið var í framkvæmd 2018. Nordic Innovation, sendiráð Norðurlanda í Peking og viðskiptaskrifstofur peirra vinna með sex borgum í Kína að verkefni sem varðar sjálfbærar borgir og borgarpróun. Páttur í verkefninu var heimsókn fulltrúa Kína til norrænna samstarfsaðila sinna á árinu 2018 og tóku peir meðal annars pátt í pingi um Norðurlönd og Kína á Nordic Edge ráðstefnunni í Stafangri í september.
Menningarsviðið ákvað sömuleiðis að fara í útrás árið 2018. Í nóvember ákvádu menningarmálaráðherrarnir að ráðast í nýtt alpjóðlegt menningarátak til að auka menningarleg samskipti Norðurlanda og annarra landa. Verkefnið byggist á góðum árangri tveggja eldri verkefna, Nordic Cool í Washington árið 2013 og Nordic Matters í Lundúnum 2017. Ákveðið verður árið 2019 hvar næsta menningarverkefni verði fundinn staður.

Samhliða öðru alpjóðastarfi var rekið öflugt kynningarstarf árið 2018. Í febrúar var verkefninu "verkfærakassi" ýtt úr vör, pað er að segja safni stafrænna tækja og tóla fyrir pá sem vilja breiða upplýsingar um Norðurlönd út um heiminn. Pað var gert í tengslum við fund samstarfsráðherra Norðurlanda í Stokkhólmi.

Í framhaldinu var kynningarherferð beint að sendiráðum norrænu landanna sem tóku virkan pátt í að boða erindi Norðurlanda á alpjóðavísu. Framtíðarstefna verkefnisins var einnig endurskoðuð.

\section{$\rightarrow$ SJÁ NÁNAR UM ALPJÓĐLEGA KYNNINGU Á NORĐURLÖNDUM}




\section{Skýrslur vöktu eftirtekt á alpjóðavettvangi}

Greiningardeild ráðherranefndarinnar, sem hóf störf árið 2017, gaf út nokkrar skýrslur árið 2018 sem vöktu eftirtekt. Skýrslan Skyggen af lykken (Hamingjuskugginn) vakti einkum mikla athygli og var engin skýrsla sótt jafnoft á netinu og hún eða alls 11.000 sinnum í ársbyrjun 2019.

Sérstaklega vakti hún athygli alpjóðlegra fjölmiðla og birtist meðal annars umfjöllun um hana í The Guardian (og var raunar mest lesna greinin í blaðinu daginn sem hún var birt), The New York Times, BBC og The Washington Post. Um skýrsluna var einnig fjallað í indverskum, áströlskum og tævönskum fjölmiðlum auk pess sem um hana var rætt í alpjóðaefnahagsráðinu World Economic Forum. Skýrslan hlaut einnig umfjöllun í norrænum fjölmiðlum, einkum dönskum.

Sjálf skýrslan tekur mið af rannsóknum sem hafa itrekað sýnt hve hamingjusamar norrænar pjóðir eru. Skyggen af lykken rannsakar skuggahliðar hamingjunnar og varpar ljósi á pá staðreynd að um pað bil tólf af hundraði íbúa Norðurlanda eru óhamingjusamir.

\section{$\rightarrow$ SJÁ SKÝRSLUNA SKYGGEN AF LYKKEN}

Önnur norræn skýrsla sem vakti mikla athygli er Is the Last Mile the Longest? Economic Gains from Gender Equality in Nordic Countries. Í peirri rannsókn er lagt mat á efnahagslegar afleiðingar ýmissa umbóta á jafnréttissviðinu fyrir samfélagið, svo sem uppbyggingu og niðurgreiðslu umönnunar barna og aldraðra og foreldraorlof. Umbæturnar hafa fjölgun kvenna á vinnumarkaði i för með sér. Skýrslan, sem OECD gaf út að beiðni ráðherranefndarinnar, sýnir að aukin atvinnupátttaka kvenna á Norðurlöndum undanfarin 40 til 50 ár hefur hækkað meðaltalstölur hagvaxtar um 10-20 prósent. Hún sýnir enn fremur að hagvöxtur á Norðurlöndum gæti aukist um 15-30 prósent í viðbót yrði atvinnupátttaka kvenna jafnmikil og karla.

Sagt var frá skýrslunni i ýmsum albjóðlegum fjölmiðlum, par á meðal Bloomberg og Le Figaro, auk pess sem henni voru gerð góð skil í norrænum miðlum. Jafnframt fékk hún góða útbreiðslu á samfélagsmiðlunum. Skýrslan var gefin út undir merkjum verkefnisins The Nordic Gender Effect at Work. I stuttu máli varpar hún ljósi á frábæran árangur af jafnréttisstarfi á Norðurlöndum sem gæti orðið öðrum löndum til eftirbreytni.

\section{$\rightarrow$ SJÁ SKÝRSLUNA IS THE LAST MILE THE LONGEST?}

The Nordic Gender Effect at Work er eitt af sex svonefndum flaggskipsverkefnum innan forsætisráðherraverkefnisins Norrænar lausnir á hnattrænum viðfangsefnum. Pví var hleypt af stokkunum vorið 2017 og var enn ofarlega á baugi árið 2018. Hugmyndin með verkefninu er að efla norræna samvinnu um sjálfbærnimarkmið Sameinuðu pjóðanna fyrir árið 2030. 


\section{Forsætisráðherraverkefnið á fullri ferð}

Auk jafnréttisverkefnisins skiluðu hin flaggskipsverkefnin fimm á vegum forsætisráðherraverkefnisins góðum árangri árið 2018.

Til dæmis flaggskipið Nordic Sustainable Cities sem talið er geta haft mikil áhrif í fimmtán borgum í Kína, Indlandi og Norður-Ameríku sem ráðgera verulegar fjárfestingar í innviðauppbyggingu. Norrænu útflutningsskrifstofurnar eru sameiginlega í sambandi við borgirnar og skapa útflutningstækifæri fyrir norræn fyrirtæki sem hefðu tæplega orðið til nema fyrir tilverknað verkefnisins. Pannig getur verkefnið orðið norrænum útflutningsskrifstofum, sendiráðum og öðrum sem hlut eiga að máli fyrirmynd að samvinnu í stað pess að allir erfiði einir og út af fyrir sig.

Flaggskipið The Nordic Food Policy Lab vakti einnig alpjóðaathygli árið 2018 enda var lögð mjög mikil áhersla á samfélagsmiðla og jafnframt á skýrsluna Solutions Menu - A Nordic guide to sustainable food policy. Petta gaf góða raun og áhugi á norrænni pekkingu á neytendamiðaðri matvælastefnu óx verulega á alpjóðavettvangi á árinu. Opinberir aðilar á Indlandi, Kosta Ríka og Skotlandi horfa nú orðið til Norðurlanda. Sama á við um stefnumótandi alpjóðastofnanir á borð við Alpjóðaheilbrigðismálastofnun, Umhverfisáætlun Sameinuðu pjóðanna, Matvæla- og landbúnaðarstofnun Sameinuðu pjóðanna og Rammasamning Sameinuðu pjóðanna um loftslagsbreytingar.

\section{$\rightarrow$ SJÁ SKÝRSLUNA SOLUTIONS MENU}

Forsætisráðherraverkefnið stendur í prjú ár (2017-2019) og byggist á flaggskipsverkefnum um borgarskipulag, svæðisbundið orkumálasamstarf, jafnrétti, sjálfbæra matvælaneyslu og snjallar velferðar- og loftslagslausnir. Verkefnið á að stuðla að útbreiðslu á norrænni pekkingu, gildum og vörum.

\section{$\rightarrow$ SJÁ NÁNAR UM FORSAETISRÁĐHERRAVERKEFNIĐ}

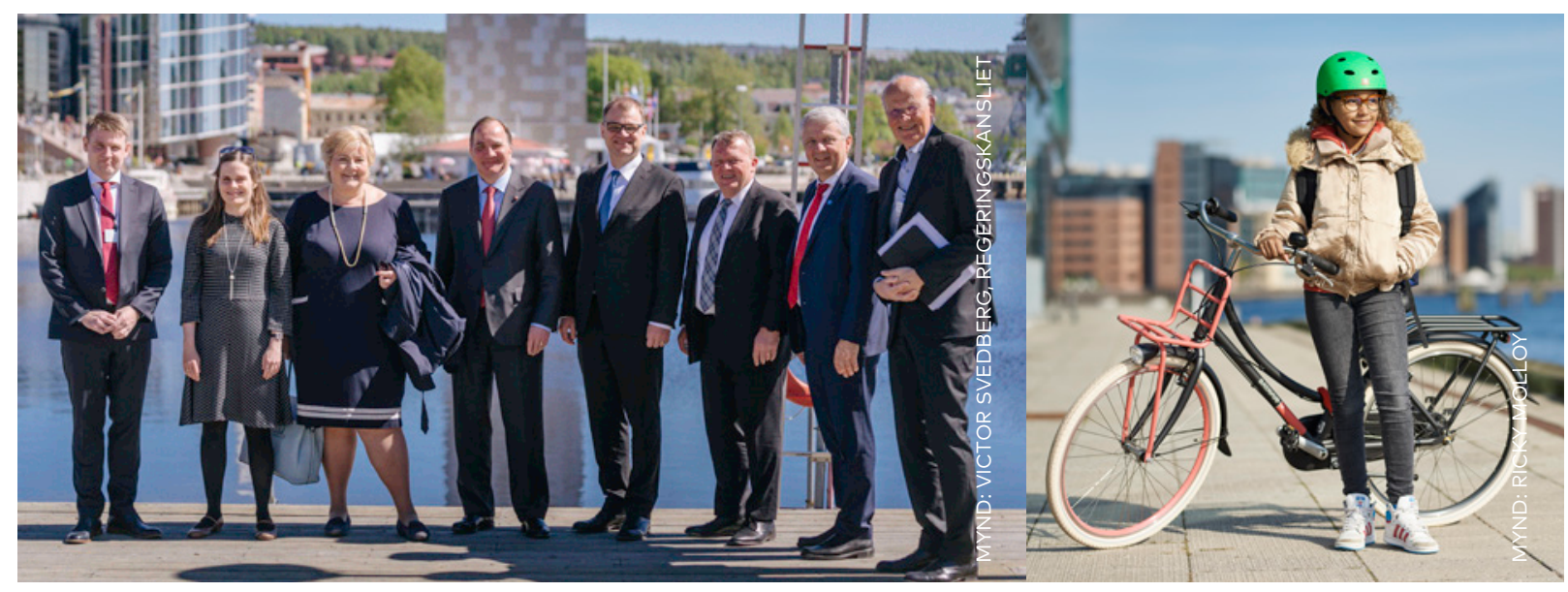




\section{Skilvirkara samstarf vegna umbóta}

Starf Norrænu ráðherranefndarinnar hefur markvisst verið nútímavætt og gert skilvirkara á undanförnum fimm árum. Umbæturnar hafa orðið til að samstarfið nær betur til málefna sem eru á dagskrá stjórnmálamanna á norrænum vettvangi en áður var. Samstarfið verður pví notadrýgra fyrir ríkisstjórnirnar, íbúana og atvinnulífið á Norðurlöndum.

Í júní var matsgerð kynnt fyrir samstarfsráðherrunum par sem bent var á ýmsa málaflokka sem umbótastarfið hafði snert. Meðal annars mátti sjá að eflt samstarf um aðlögun, stafvæðingu, málefni ESB, loftslagsmál og atvinnulíf hafði borið góðan árangur.

Flest framangreindra verkefna eru unnin pvert á sviðin og fjármögnuð fyrir sakir aukins sveigjanleika í fjárhagsáætlun og skipulagi hjá ráðherranefndinni - en hann er einnig afleiðing af umbótastarfinu. Meiri skilvirkni hefur svo aftur í för með sér að norrænu löndin hafa fengið meiri trú á samstarfinu. Ríkisstjórnirnar gera orðið meiri kröfur til Norrænu ráðherranefndarinnar og vænta einnig meira af henni.

Stefnumótandi úttektir hafa skipt miklu fyrir aukna skilvirkni en pað eru greiningar sem varpa ljósi á vaxtarmöguleika norræns samstarfs á tilteknum sviðum næstu 5 til 10 ár. Utanaðkomandi aðilar hafa fram að pessu rannsakað samstarfið á sviði heilbrigðismála, umhverfismála, löggjafar og félagsmála og nú pegar má sjá árangur íýmsum greinum.

\section{$\rightarrow$ SJÁ ÚTTEKTINA Á SVIĐI LÖGGJAFARSAMSTARFS}

\author{
$\rightarrow$ SJÁ ÚTTEKTINA Á SVIĐI \\ FÉLAGSMÁLA
}

Gerðar voru tvær úttektir á árinu 2018. Norðmaðurinn Inge Lorange Backer, prófessor emeritus, gerði úttekt á löggjafarsamstarfinu og skilaði prettán tillögum sem geta stuðlað að pví að Norðurlönd verði sampættasta svæði heims. Árni Páll Árnason, fyrrverandi félagsmálaráðherra Íslands, gerði stefnumótandi úttekt á samstarfinu á sviði félagsmála. Par er að finna fjórtán tillögur að samstarfi í breyttri mynd.

Auk pessara úttekta annaðist Idar Kreutzer, framkvæmdastjóri Finans Norge, greiningu á norrænu samstarfi um nýsköpunar-og sprotafyrirtæki og skilaði skýrslu með sextán tillögum að auknu samstarfi.

\section{$\rightarrow$ SJÁ SKÝRSLUNA UM FJÁRMÖGNUN NÝSKÖPUNAR- OG SPROTAFYRIRTAEKJA}



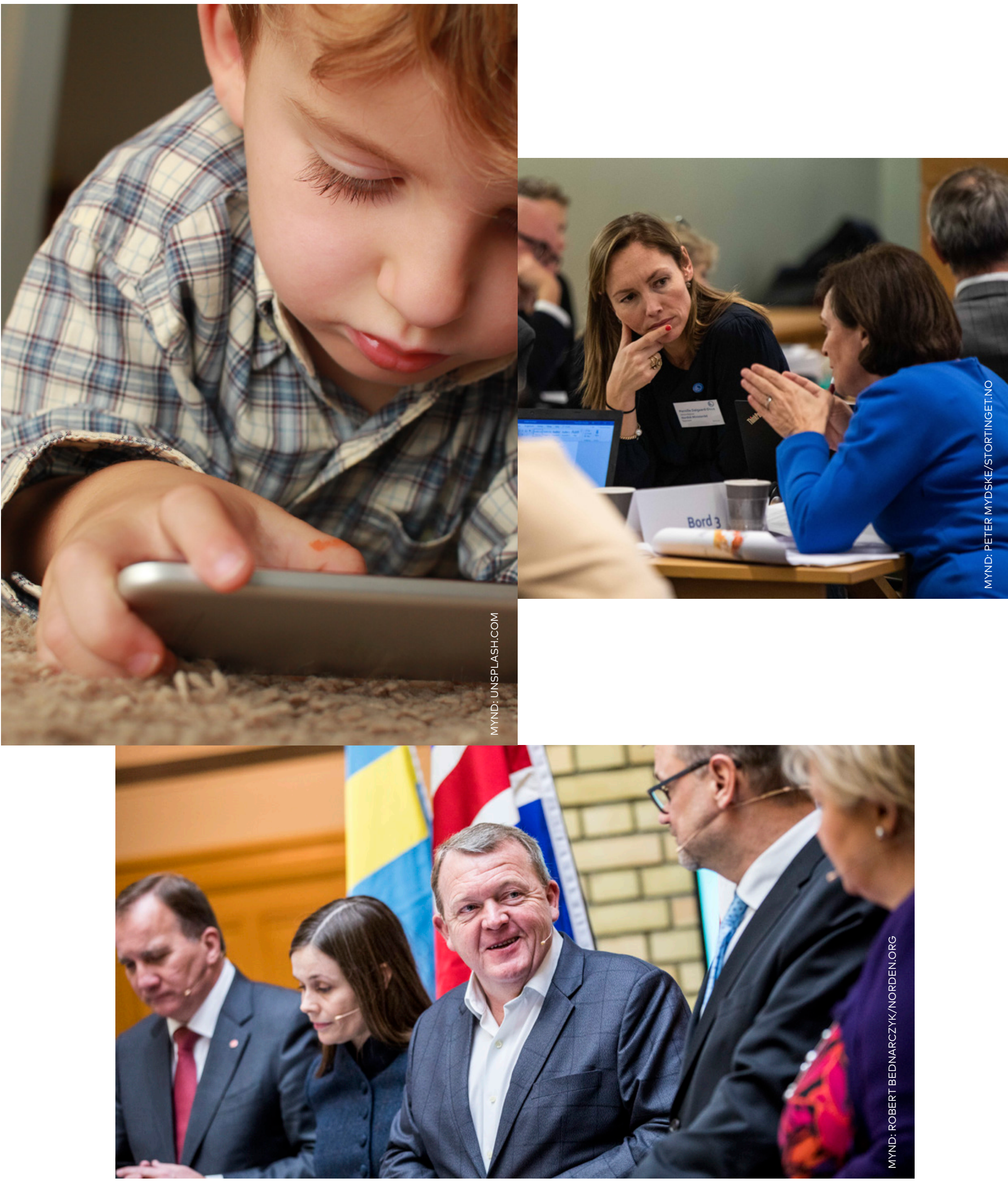


\section{Norræna ráðherranefndin}

Nordens Hus

Ved Stranden 18

DK-1061 Kaupmannahöfn

www.norden.org

Mikið var um að vera hjá Norrænu ráŏherranefndinni á árinu 2018 og kom greinilega í ljós að norrænt samstarf skilar raunverulegum árangri á mörgum sviðum, bæði innan Norðurlanda og utan. Í pessari samantekt má lesa nokkuð um ávinninginn af norrænu samstarfi árið 2018. Ekki er um tæmandi umfjöllun að̆ ræða en kastljósinu er beint að nokkru af pví sem vegur byngst. 